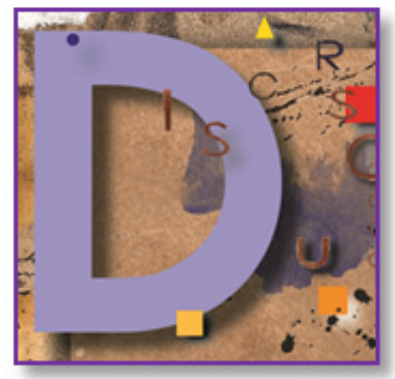

DISCURSOS CONTEMPORÄNEOS

EM

ESTUDO

ISSN 2237-7247

\section{MACHIN, D.; VAN LEEUWEN, T. Discurso da mídia global: uma introdução crítica. Nova Iorque: Routledge, 2007. 188 p.}

David Machin é conferencista do Departamento de Mídia e Comunicação na Universidade de Leicester, Reino Unido. Theo van Leeuwen, atualmente, é Decano na Faculdade de Humanidades e Ciências Sociais na Universidade de Tecnologia em Sidney, Austrália.

A obra Discurso da mídia global: uma introdução crítica nos fornece uma acessível e vivaz introdução sobre como a globalização está mudando a linguagem e as práticas comunicativas da mídia. Apresentando grande variedade de exercícios, de exemplos e de imagens, oferece uma maneira prática de analisar os discursos das indústrias da mídia global. Com base em uma introdução compreensiva da história e da teoria da comunicação da mídia global, apresenta estudos de caso com exemplos reais de situações ao redor do mundo. O livro investiga como a comunicação da mídia global é produzida, olhando para os formatos, as linguagens e as imagens utilizadas na criação de materiais midiáticos tanto mundialmente, quanto localmente.

Escrito em estilo acessível, compõe-se de introdução e de três seções divididas em capítulos. Introduzindo a obra, Machin e van Leeuwen deixam claro que não é difícil perceber o processo de globalização da mídia. De acordo com os autores, as indústrias mundiais (globais) de cultura agora produzem e distribuem a consciência de todos nós, ou seja, temos as mesmas telas de filmes, os mesmos programas de televisão. Além disso, os mesmos noticiários são mostrados em toda parte, embora, às vezes, em versões locais e específicas. Ao mesmo tempo, novas formas de migração têm trazido mais diversidade cultural às grandes cidades das nações europeias do que estas já haviam visto ao longo dos anos. Ao lado dos principais meios de comunicação global, as migrações buscam chegar a todos, em qualquer parte. Portanto, não há mais apenas a mídia nacional, mas também uma diversidade de outros meios de comunicação que fornecem, globalmente, informações para as comunidades étnicas, às vezes, produzidas localmente.

\footnotetext{
${ }^{1}$ Doutora em Linguística (UnB).
} 
Ainda na introdução, os autores revelam que os Estados nações têm tentado manter-se longe do que eles consideram ameaças contra suas crenças e seus modos de vida a fim de conter essa maré e de preservar a unidade de seus meios nacionais de comunicação. Para exemplicar essa situação, os autores mencionam a resistência da Holanda contra a televisão a cabo em 1980; a China e o bloqueio de fontes de mídia, como a CNN, a NBC e o The Washington Post, de sítios de notícias da $\mathrm{BBC}$ e de vários outros meios de comunicação ocidentais de entretenimento. Outro exemplo é o da Indonésia, país no qual o editor e a modelo da capa da primeira edição local da Playboy foram acusados de indecência por mostrarem "a decadência ocidental".

Machin e van Leeuwen mostram, ainda, que as indústrias da mídia global têm respondido, deliberadamente, por meio de uma diversidade de criação, produzindo mídia global em linguagens locais e integrando o conteúdo local de várias formas.

Na primeira seção do livro, intitulada Contextos, os autores apresentam a história da globalização da mídia e um panorama dos temas principais da teoria da globalização. Compondo essa primeira parte, o Capítulo 1, Histórias da globalização da mídia, discute o crescimento da mídia global focalizando uma das principais questões teóricas da globalização que é a homogeneização da cultura mundial por meio da mídia ocidental e dos valores e dos tipos de identidade que ela promove. Aqui, os autores olham para os exemplos das formas mais recentes da mídia global e mostram como seu crescimento no domínio global formou uma parte do projeto dos Estados Unidos que era, ao mesmo tempo, econômico e ideológico.

O Capítulo 2, intitulado Teorias da globalização da mídia, trata da questão da definição da globalização da mídia. Discute também as diferentes formas como a mídia global, seus formatos e estilos encontram seus caminhos na sociedade.

Já na segunda seção, Discursos , o Capítulo 3, Discursos de identidade e comunidade, enfatiza que a mídia global gera tipos de identidade e de comunidade diferentes daqueles criados nas nações Estados. Ressalta que esses novos tipos de identidade servem aos interesses do capitalismo de consumo global, levando as pessoas a desempenharem um papel ativo na sua produção.

O Capítulo 4, Discursos do sexo e trabalho, trata especificamente do tipo de identidade ideal que a mídia global cria para as mulheres. Os autores destacam a revista Cosmopolitan, a qual se apresenta em diferentes versões ao redor do mundo, propagando o ideal feminino de mulher divertida e destemida, criando um mundo de fantasia por meio de imagens de modalidade baixa, a qual permite um tipo de agência para significar o poder. As realizações multimodais do discurso da revista permitem, às mulheres, um tipo de alinhamento com o seu mundo, isto é, as roupas que elas vestem, os lugares que frequentem e a forma como dançam estão diretamente associados ao discurso da revista, não ao mundo real, mas ao mundo de fantasia e de prazer.

O Capítulo 5, Discursos de guerra, explora como a guerra contra o terrorismo está representada em jogos de guerra de computador, mostrando que a indústria americana de jogos de computador, hoje, é maior que a indústria de filmes de Hollywood. Muitos dos jogos que são produzidos tratam da guerra e estão intimamente modelados em eventos reais pretendendo, explicitamente, auxiliar na guerra contra o terror. 
$\mathrm{Na}$ terceira seção do livro, Linguagem e imagem, Machin e van Leeuwen ressaltam que as formas e os formatos da mídia global de hoje não são neutros, uma vez que podem moldar e limitar o seu próprio conteúdo. Segundo os autores, gêneros da mídia global, como notícias, novelas, filmes e anúncios publicitários, juntamente com a linguística e com os estilos visuais comunicam valores e identidades não apenas por meio do seu conteúdo, mas pela sua estrutura, pela forma como se dirigem ao seu público-alvo. Enquanto o conteúdo é geralmente localizado, formas e formatos da mídia tendem a ser globais, dirigindo-se às pessoas da mesma forma ao redor do mundo, independentemente de nacionalidade ou de conhecimento cultural.

No Capítulo 6, o primeiro dessa terceira seção e intitulado Gêneros globais, os autores dão atenção ao gênero usando, mais uma vez, o exemplo da revista feminina Cosmopolitan para mostrar como o mesmo gênero de comunicação é utilizado nos domínios do trabalho, do sexo, dos relacionamentos e da moda favorecendo maneiras particulares de ação e de identidade e ofuscando as diferenças entre essas esferas da vida. Eles olham para um gênero particular que permite à revista oferecer determinado poder às mulheres, poder esse que somente será obtido por meio do consumo de mercadorias e de serviços globais, os quais, embora possam ser localizados em certo grau, têm uma uniformidade global sempre visível.

O Capítulo 7, Linguagens globais, discute os estilos de linguagem, os quais podem ser produzidos pela mídia global em diferentes versões de seus produtos em linguagens locais. Os autores ressaltam que essas linguagens, contudo, devem-se adaptar aos requisitos dos formatos da mídia global.

No Capítulo 8, Imagens globais, os autores tratam da linguagem visual global, na qual não é apenas o conteúdo que importa, mas, especialmente, a sua forma. As imagens, globais, são projetadas para aparecerem bem na página, para se harmonizarem com os anúncios publicitários e para serem reutilizáveis. Por essa razão, elas raramente se referem a pessoas, a lugares e a eventos específicos. Em vez disso, trabalham com repertório limitado de motivos simbólicos para comunicar o tipo de conceitos e de valores que a mídia global pode ilustrar.

No Discurso da mídia global, Machin e van Leeuwen nos presenteiam com discussões e com reflexões acerca da mídia no mundo globalizado, mostrando que a globalização tem o poder de mudar a linguagem e as práticas comunicativas da mídia, ultrapassando limites e provocando certa homogeneização cultural entres os povos. As distâncias já não importam mais, pois o que está sendo apresentado é o fim da geografia em termos de espaço, o que torna as fronteiras meras formas simbólicas e sociais: "a distância é um produto social; sua extensão varia dependendo da velocidade com a qual pode ser vencida" (BAUMAN, 1999, p. 19). Essa redução das distâncias e o fim da geografia espacial são consequências do efeito da velocidade das informações e dos meios de comunicação, assim como de um crescente desenvolvimento de novas tecnologias.

O Discurso da Mídia Global traz uma excelente reflexão a respeito dos fenômenos da mídia global e do que ela tem feito em termos de divulgação e de propagação do discurso de determinada agência, considerando não um público local, mas, sim, global, sem fronteiras para alcançar os seus objetivos, criando assim novas identidades, novos estilos de vida por meio de um alinhamento de práticas e valores com o consumo de mercadorias e serviços compartilhados globalmente. 


\section{Referências}

BAUMAN, Zygmunt. Globalização: as consequências humanas. Rio de Janeiro: Jorge Zahar Editor, 1999.] 